\title{
Formation and Destruction of Pastoral and Irrigation Landscapes on the Mughan Steppe, North-Western Iran
}

\section{Citation}

Alizadeh, Karim and Jason A. Ur. 2007. Formation and destruction of pastoral irrigation landscapes on the Mughan Steppe, north-western Iran. Antiquity 81(311): 148-160.

\section{Published Version}

http://antiquity.ac.uk/ant/081/ant0810148.htm

\section{Permanent link}

http://nrs.harvard.edu/urn-3:HUL.InstRepos:4269028

\section{Terms of Use}

This article was downloaded from Harvard University's DASH repository, and is made available under the terms and conditions applicable to Other Posted Material, as set forth at http:// nrs.harvard.edu/urn-3:HUL.InstRepos:dash.current.terms-of-use\#LAA

\section{Share Your Story}

The Harvard community has made this article openly available. Please share how this access benefits you. Submit a story.

Accessibility 


\title{
Formation and destruction of pastoral and irrigation landscapes on the Mughan Steppe, north-western Iran
}

\author{
Karim Alizadeh ${ }^{1} \&$ Jason A. Ur ${ }^{2}$
}

CORONA satellite photography taken in the 1960s continues to reveal buried ancient landscapes and sequences of landscapes - some of them no longer visible. In this new survey of the Mughan Steppe in north-western Iran, the authors map a 'signature landscape' belonging to Sasanian irrigators, and discover that the traces of the nomadic peoples that succeeded them also show up on CORONA - in the form of scoops for animal shelters. The remains of these highly significant pastoralists have been virtually obliterated since the CORONA surveys by a new wave of irrigation farming. Such archaeological evaluation of a landscape has grave implications for the heritage of grassland nomads and the appreciation of their impact on history.

Keywords: Sasanian, Iran, aerial survey, archaeological formation process, CORONA satellite survey, landscape evaluation

\section{Introduction}

The palimpsest model of archaeological landscapes describes how natural and cultural processes will damage or erase some early features but allow others to survive to some degree (Crawford 1953: 51). In a brief statement, Christopher Taylor observed that in the case of Britain, these processes are not random but patterned into what he called 'Zones of Survival and Zones of Destruction', roughly divided into the preserved uplands, where post-Saxon settlement and cultivation were uncommon, and the heavily damaged lowlands, which had been the locus of most medieval and later activities (Taylor 1972). Tom Williamson expanded Taylor's concept, demonstrating that the 'complex kaleidoscope of patterned creation and structured destruction' could be related to soil conditions and potential agricultural productivity within regionally specific historical trajectories (Williamson 1998: 6). The pattern of Roman sites in marginal chalk downland and upland moors tells us less about settlement and land use in the Roman period than it does about the archaeological consequences of later agricultural expansion.

The palimpsest model is particularly appropriate in the Near East, where settlement histories extending back eight millennia or more make the unravelling of the surviving features an imposing task. In an authoritative synthesis of landscape processes and histories throughout

1 Iranian Center for Archaeological Research, Bahârestan Sq-Ekbâtân Ave., Emarate Masoudieh, 11416, Tehran, Iran(Email: ksalizadeh@yahoo.com)

2 Department of Anthropology, Peabody Museum, Harvard University, 11 Divinity Ave., Cambridge, MA 02138, USA (Email: jasonur@fas.harvard.edu) 
the region, T.J. Wilkinson (2003) has extended the work of Taylor and Williamson. Wilkinson's landscape taphonomy concept (2003: 41-3) describes the processes by which ancient landscapes are erased, recycled, or retained; in particular, he demonstrates that patterns of survival and destruction can be generally associated with certain environments and 'signature landscapes'. Features in desert and highland environments, for example, are less likely to be effaced because the marginality of these regions does not encourage human resettlement. On the other hand, due to their inherent agricultural productivity, lowlands are likely to be the focus of long-term settlement which will remove earlier landscapes. Wilkinson's 'signature landscapes' concept (Wilkinson 2003: 11, 214-15) emphasises the human aspect of landscape taphonomy, referring to general classes of cultural landscapes that were so profoundly inscribed, through either large-scale intentional action or via long-term persistence, that they structured subsequent landscapes and were more likely to remain visible to the present.

Signature landscapes are the most likely to survive and to continue to structure the landscape, but they also remove more lightly inscribed features. The signature landscape par excellence for lowland areas of the Near East is composed of nucleated settlements and associated irrigation canals. Irrigation is an intensive land use strategy designed to increase agricultural yields and reduce risk, and is particularly associated with urban settlement patterns and high population densities (Wilkinson 2003: 71-2). At the opposite end of the continuum of land-use-intensity resides another classic Near Eastern pattern: pastoral nomadism. This economic adaptation stresses resilience over maximisation of yields and is successful under conditions of low population densities; it uses mobility as a response to economic adversity (Salzman 2004; Abdi 2003). The landscape history of the Near East is to a great extent the cyclical waning of one of these strategies and the corresponding waxing of the other.

Under the often antagonistic relationships between pastoral nomads and sedentary agriculturalists, the former will have their phases of political dominance, but in the larger sweep of landscape evolution, it is the remains of the latter that persevere. Nomad campsites are notoriously difficult to identify (Cribb 1991); more often, what we know of them is derived from the written accounts of their sedentary neighbours, and these can reflect the mistrust and prejudices that exist between farmers and pastoralists (Buccellati 1966). When the archaeological remains of nomadic groups can be found, the question of how representative they are of the larger landscape is rarely resolvable.

This study will examine the taphonomic processes which result in the patterned creation and structured destruction of these two dramatically different landscape signatures on the Mughan Steppe in Ardebil Province, north-western Iran, a region that has been simultaneously blessed by a striking oscillation between these strategies and cursed by the rapid increase in the pace of the most destructive taphonomic processes in recent times. Using historical CORONA satellite photography (see most recently Fowler 2004; Gheyle et al. 2004), field survey and the ethnohistoric record, we show how the expansion of irrigation selectively removed some traces of pastoral nomads and left a pattern that could easily be misinterpreted. Rather than being a new phenomenon related to modern industrial society, we suggest that the removal of nomadic remains by the recent expansion of irrigation agriculture is only a technologically amplified version of a taphonomic process which existed in antiquity as well. 


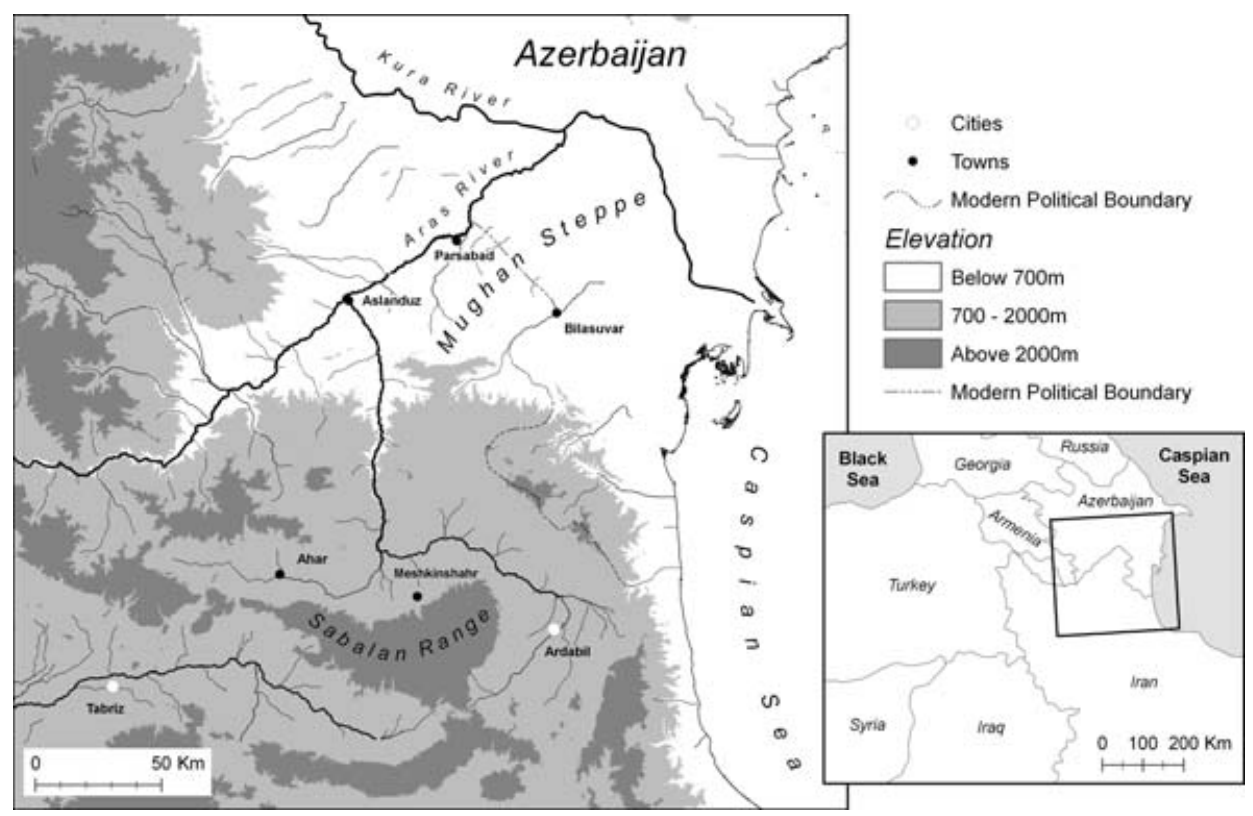

Figure 1. The Mughan Steppe, north-western Iran.

\section{The Mughan Steppe}

The Mughan Steppe is a broad low plain along the south bank of the Aras (Araxes) river, toward the end of its course where it meets with the Kura and flows into the Caspian Sea (Figure 1). Since the delineation of the Russian-Iranian frontier in 1813, the south-western third of the steppe lies in the Islamic Republic of Iran; the majority is now part of the Republic of Azerbaijan. The Aras floodplain today is heavily incised in some places: on its south bank, the steppe terrace stands some $15 \mathrm{~m}$ above it. To the south of the steppe, the terrain rises to undulating highlands (occasionally reaching $700 \mathrm{~m}$ ) and ultimately to the Sabalan mountain range near Ardebil (Tapper 1979: 23-7; Schweizer 1970). The soils of the steppe are well developed with good agricultural potential, as are several intermontaine plains near Ardebil and the basin of Sarab.

The influence of the Caspian Sea results in relatively mild winters, reaching a low of $3^{\circ}-5^{\circ} \mathrm{C}$ in January. Rainfall is seasonal, mostly falling in the late fall and early spring. The average yearly rainfall is just under $300 \mathrm{~mm}$, which means that dry farming is possible if biennial fallow is practiced; however, it is risky and the various state-sponsored attempts in the twentieth century were not considered successful (Schweizer 1974).

These climatic and geographic considerations make the steppe particularly well-suited for use as pasture, the dominant mode of land use for the last millennium. Because of its location close to water sources and within close migratory distance to upland pasture, the large grassy plain has served as winter pasture ground for Kurds, Ghuzz Turks, Mongols and most recently the Shahsevan tribal confederation, about whom we are particularly knowledgeable from the work of the anthropologist Richard Tapper (1979; 1997). In the last century, the pendulum has swung toward the dominance of agriculture, in particular, 
a series of state-sponsored irrigation schemes (Schweizer 1970; 1974). The corresponding reduction in pasture, along with varying degrees of pressure from the Iranian government, has resulted in the almost complete settlement of the Shahsevan.

The Mughan Steppe Archaeological Project (MSAP) aims to investigate the processes by which land use on the plain oscillated between such poles of intensity. Archaeological work began in 2004 with soundings at Ultan Qalasi, a fortified site on the Aras terrace edge (Alizadeh 2004). In January of 2005, an initial season of survey was undertaken, during which we conducted low intensity reconnaissance throughout the steppe and targeted several discrete zones for more intensive observation, including walking transects. Our intentions were to develop a general understanding of the characteristics of the archaeological landscape, assess the extent of transformations by recent development, and to gain ground control for the interpretation of the CORONA satellite photographs which serve as our primary means of site and feature identification. This short season revealed the general outlines of widely fluctuating land-use practices over several millennia and their taphonomic impacts, upon which we report here.

\section{Irrigation on the Mughan Steppe}

The earliest occupation of the region is as yet poorly understood, being composed of scatters of worn stone tools in the uplands. Sites of the Early Bronze and Iron Ages appear to be of the classic Near Eastern tepe (Persian) or tell (Arabic) morphology: nucleated mounds of superimposed settlement debris, suggesting long-term continuous settlement or preferential reoccupation, exemplified by the site of Nader Tepesi near Aslandouz (Mohammadi 2004). Several mounds show the distinct ceramics of the Kura-Araxes culture, which extended across a broad area of the northern fertile crescent (Sagona 1984). These sites are clustered along the edge of the Aras River terrace; thus far we have recovered little evidence for the use at this time of the broader steppe to the south.

At present, the earliest coherent signature landscape in the Mughan Steppe can be attributed to the Sasanian period (AD 224-642). From their ancestral homeland in the Fars region of southern Iran, this dynasty overthrew the Parthian rulers of Iran to form an empire stretching from Syria to the Indus (Frye 1983). In western historical sources, they are best known as the greatest rivals of Rome and Byzantium (Dodgeon \& Lieu 1991). Accounts by Arab historians (al-Tabari 1999) contain equal parts of historical information and fanciful anecdotes. Unfortunately, contemporary Sasanian sources tend to be limited to short inscriptions on seals and coins (Gyselen 2002) and a few longer texts on monuments (Huyse 1999).

Although broader syntheses are beginning to appear (Simpson 1996; 2000), archaeological studies have generally focused on two aspects of the Sasanian empire. Art historical topics have received much scholarly attention, especially rock reliefs, seals and metalwork, much of the latter unprovenanced (Curtis et al. 1998). On the other hand, Sasanian settlement and state-sponsored irrigation projects in southern Iraq and southwestern Iran have attracted the attention of archaeologists. Adams (1965) argued that the enormous Nahrawan canal exploited the entire flow of the Diyala River, a left bank tributary of the Tigris at Baghdad. Building on Adams' earlier work, surveys in Khuzistan and 

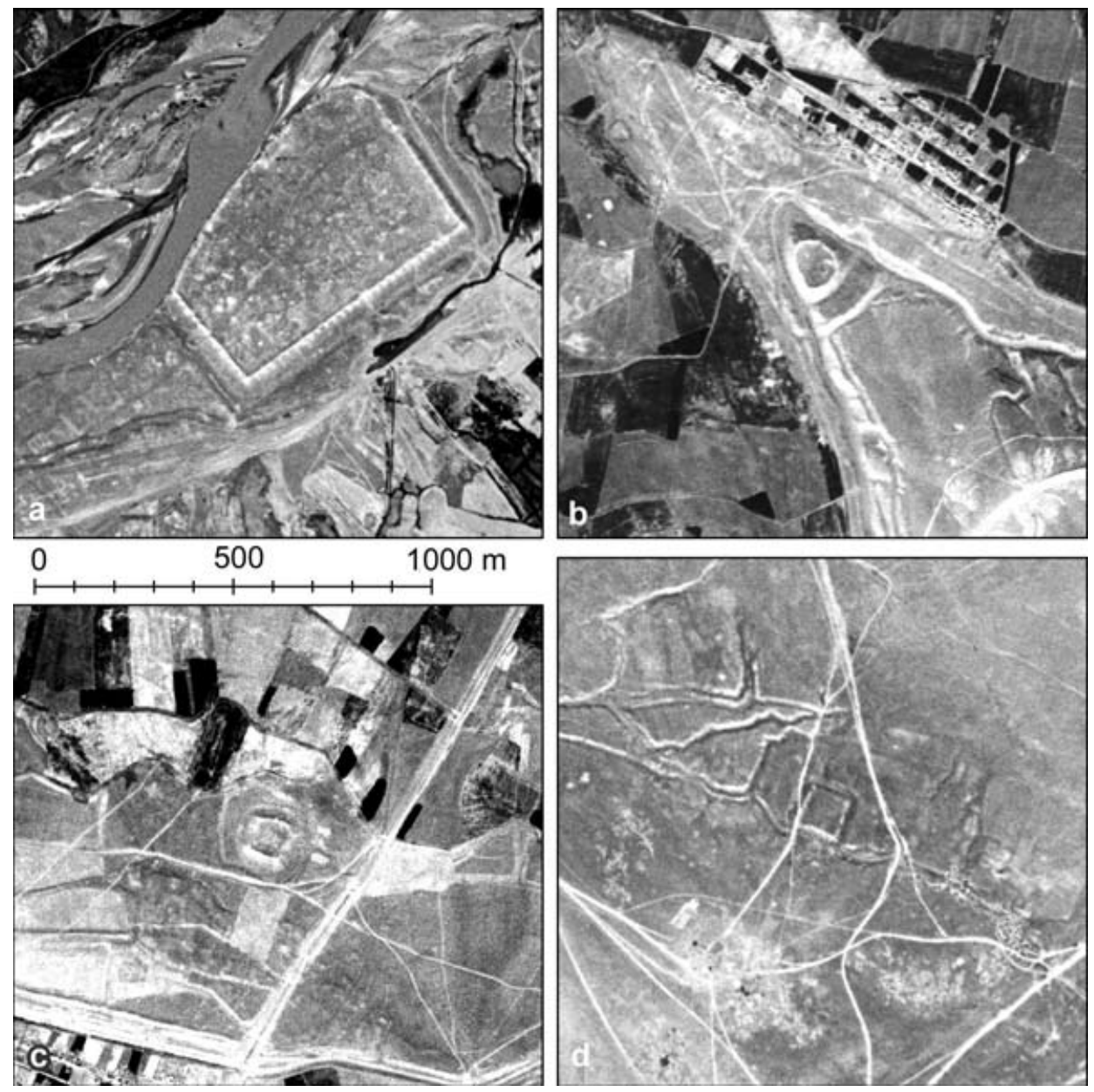

Figure 2. CORONA photographs of fortified settlement complexes of the Sasanian period. a. Ultan Qalasi (11101154DA065, 30 May 1970); b. Nadir Tepesi (1103-1057DF074, 5 May 1968); c. Qara Tavara (1103-1057DF074, 5 May 1968); d. Qishlaq Qaravol (1110-1154DA065, 30 May 1970). All photographs courtesy of the USGS.

Deh Luran have demonstrated dense population and elaborate irrigation systems (Neely 1974; Wenke 1989; Alizadeh et al. 2004). Tax revenue data recorded by later Islamic writers attest to the high productivity of these systems (Christensen 1993), and the combined landscape data shows an intensity of irrigation unrivalled in pre-modern times.

A similar agricultural landscape was created on the Mughan Steppe. The Sasanian settlement system on the Mughan Steppe was dominated by a series of rectangular fortified sites, of which Ultan Qalasi (28ha) is the largest. The rectilinear fortified components otherwise range from $100 \times 100 \mathrm{~m}$ down to $30 \times 30 \mathrm{~m}$. On the surface, they stand up to $5 \mathrm{~m}$ high, with flat or slightly concave tops which give them a walled appearance on CORONA photographs (Figure 2). In all cases extensive extramural settlement surrounded them; their signatures on CORONA photographs have the mottled appearance of low undulating topography, known to be typical of late settlement elsewhere in the Near East (Ur 2003). 


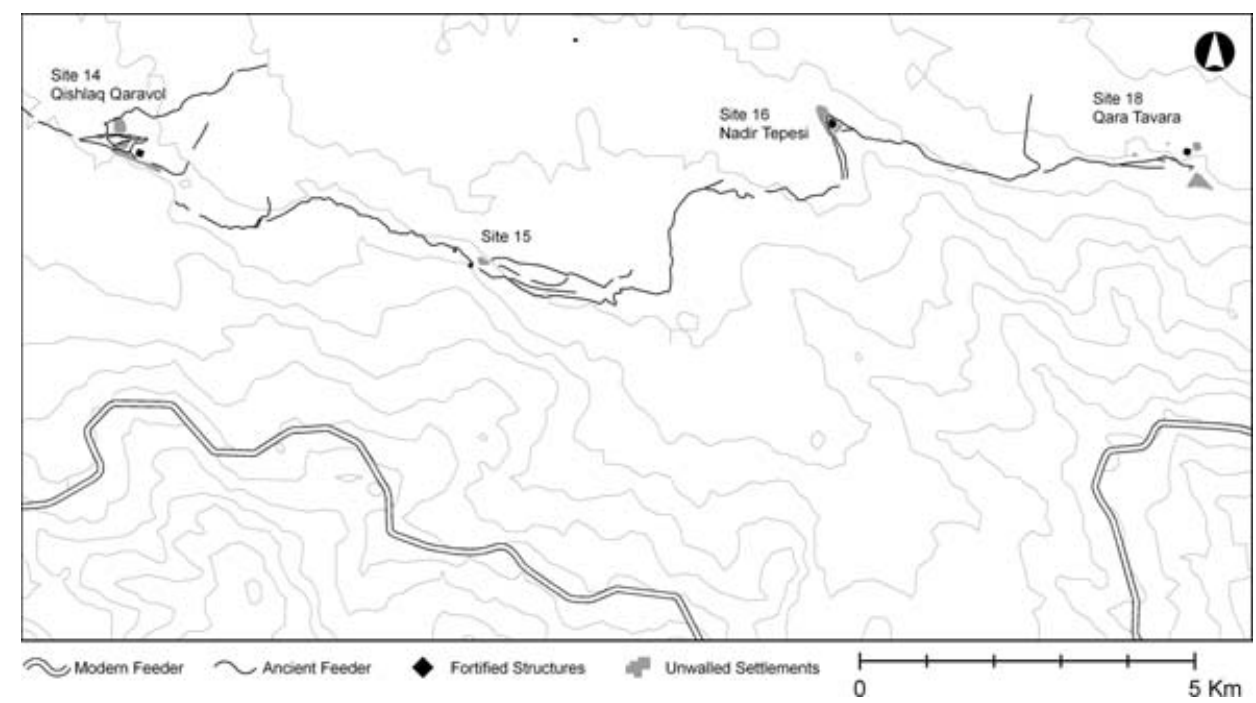

Figure 3. Sasanian settlements and canals along the foothill edge. Contour intervals at $10 \mathrm{~m}$. See also Figure 2b-d.

However, levelling and irrigation over the last 30 years have removed most of the ancient topography; all that remains are sherd scatters.

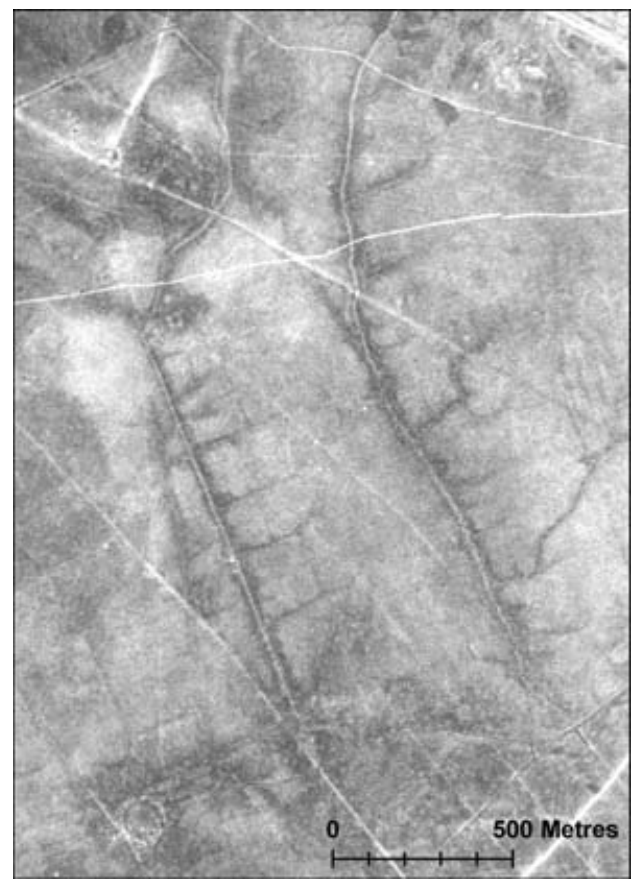

Figure 4. Irrigation networks on the Mughan Steppe. CORONA 1103-1057DF074 (5 May 1968) courtesy of the USGS.
These sites were positioned at regular intervals along the edge of the Aras River terrace or at the interface of the steppe and the foothills to the south. This distribution was not coincidental; in all cases they are found in close association with large feeder canals. Those canals associated with the Aras terrace sites are preserved in small segments, the majority having been removed by twentiethcentury agricultural projects. The sites at the foothill edge, however, are strung along a substantial canal which is in many places still in use as a drain; segments no longer visible on the ground can be reconstructed from the satellite photographs (Figure 3). Several of these settlement complexes must have overseen major weirs which fed distributary canals, which in turn must have fed elaborate networks of small canals. The latter are preserved on CORONA photographs but entirely erased on the ground (Figure 4).

Although our research is at an early stage, it is tempting to equate this type of settlement 


\section{Pastoral and irrigation landscapes on the Mughan Steppe}

complex with the Persian dastkart. The term originally described a small household and its associated land, but by the fifth century AD, it signified a rural estate, including a residence (often fortified), various outbuildings and irrigation infrastructure as well as the land it cultivated (Pigulevskaja 1963: 151-3). The term could apply at a number of scales, from the estates of lesser nobles to the rural domain of the Sasanian ruler. The relatively modest fortified rural complexes on the Mughan Steppe might have been the domain of dehqans, members of a class of landed minor nobles that emerged from the land reforms of the late Sasanian king, Khusrau I in the sixth century AD (Tafazzoli 2000: 38-48). If these were non-local nobles granted land by the king, they may have been part of a strategy to exploit underused agricultural land while solidifying the Persian presence in a non-Persian part of the empire. At the same time, these settlements would have served as an additional line of defence against nomadic intrusions via the Caspian littoral, a region historically susceptible to such invasions from north of the Caucasus mountains (Frye 1977).

\section{Mughan as a pastoral zone}

At some point after the seventh century AD, most of the elaborate settlement system was abandoned and its irrigation infrastructure went out of use. The chronology of this collapse is unclear; certainly the settlement at Ultan Qalasi (ancient Warthan) remained a functioning urban centre into the tenth century (Le Strange 1905: 175-6), and the intensively surveyed sample area east of Aslandouz suggests that a few small villages may have clung to the terrace edge throughout the Islamic period. It is possible that abandonment coincided with the Islamic conquest and the collapse of the Sasanian state in the mid-seventh century; the absence of Islamic sherds on the fortified settlements along the canals at the southern foothills appears to support this possibility. The irrigation system had certainly collapsed by the late ninth century, however, when the traveller Abu Dulaf noted that In this plain there are 5000 villages or more, all in ruins, although their walls and buildings stand upright without decay in view of the goodness of the soil' (Abu Dulaf 1955: 36). Mughan was the domain of Kurdish and, starting in the eleventh century, Ghuzz Turkish pastoral nomads prior to the arrival in the thirteenth century of the Mongol Ilkhans. The latter used Mughan as winter quarters (Smith 1999), as did Timur (Tamerlane) a century later.

The various Kurdish and Turkish groups coalesced into the Shahsevan tribal confederacy early in the eighteenth century (see Tapper 1997 for a detailed history). Shahsevan tribes spent the summers on the slopes of Mount Sabalan near Ardebil and undertook a short migration to their winter grazing grounds on the Mughan Steppe (Tapper 1979; Schweizer 1970). In 1870, a Russian observer estimated that the tribes included over 12000 households, with 30000 horses, 30000 camels and almost 2000000 sheep (cited in Tapper 1997: 175).

The remains of many Shahsevan nomadic campsites survive today in certain parts of the steppe. In the 1960s, the Shahsevan wintered in camps of 10-15 closely related households, although in earlier times these camps had been much larger. The Shahsevan tent (Op't Land 1966) is of the rounded Central Asian type and leaves little trace when packed up for migration. However, the Mughan winter can be very cold, so long and narrow semisubterranean shelters were constructed for the animals (Schweizer 1970: 128; Tapper 1979: 


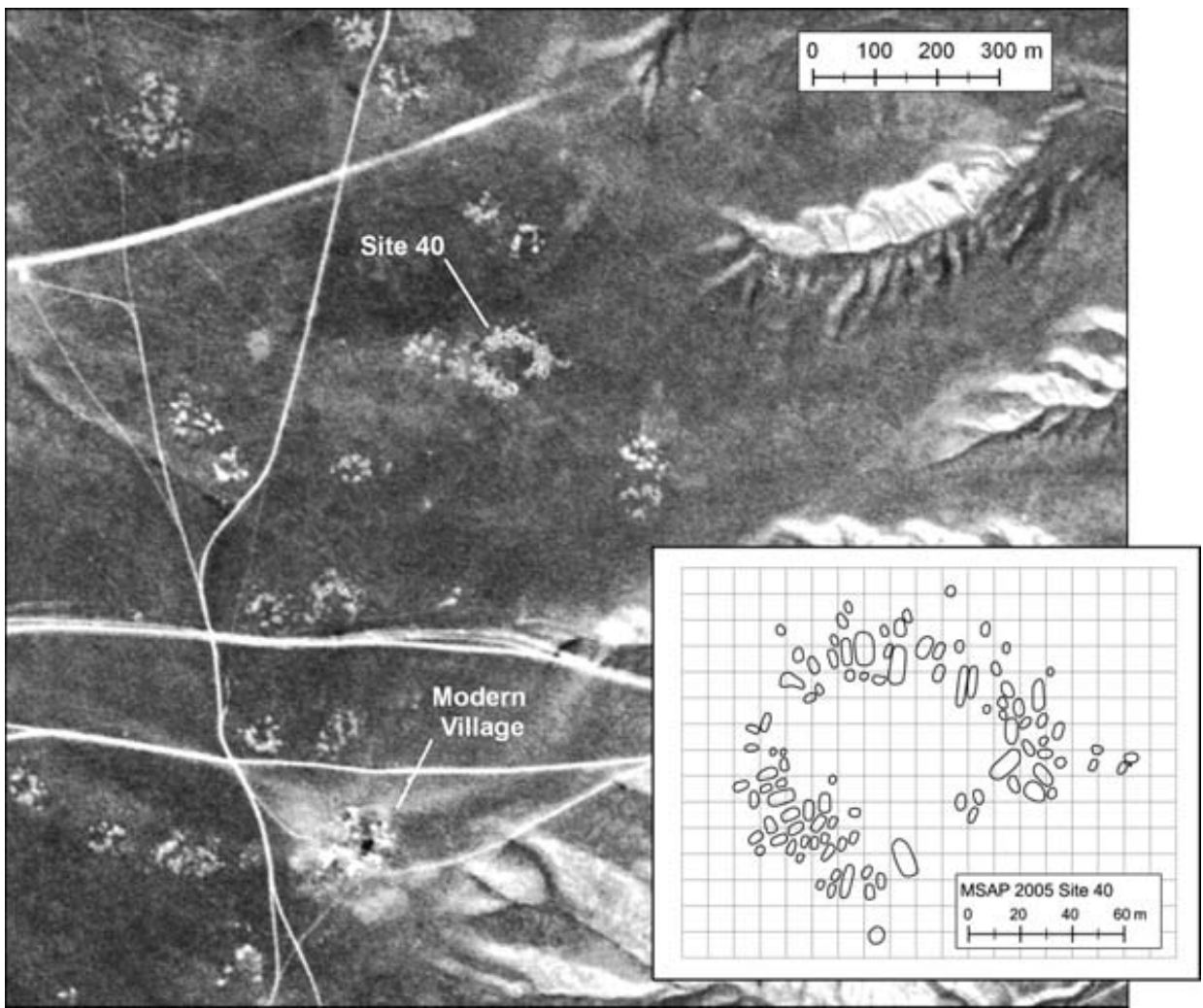

Figure 5. Abandoned Shahsevan campsites in the Mughan uplands. Light lines represent modern tracks. CORONA 11101057DA111 (24 May 1970) courtesy of the USGS. Inset: GPS-based field plan of Site 40.

85-86). The abandoned campsites visited by the survey featured little in the way of surface artefacts, but the remains of the animal shelters, in the form of shallow depressions bordered by low spoil heaps (backdirt piles), were easily recognisable from the ground and especially from a vertical perspective.

At the time the CORONA photographs used in this study were taken (May 1968 \& May 1970), the spoil heaps had neither eroded nor been recolonised by vegetation; as a result, they are highly reflective and appear distinctly lighter than the surrounding terrain (Figure 5). In the case of some of the larger animal shelters, the depressed centre had collected moisture and was hosting denser growth; these footings appear as light ovals. Although highly variable, these excavated shelters were arranged in a circular pattern, often with open space to one side.

It became clear that despite their ubiquity across the steppe in historical CORONA photographs, today campsites survive disproportionately in the uplands. Our upland survey was limited to two sample areas in our first season, because our primary goal was to gain ground control for these distinctive signatures on the imagery. Armed with such interpretive ability, we have been able to map the distribution of campsites well beyond our limited areas of ground survey. We arbitrarily selected a sample area $10 \mathrm{~km}$ wide and $26 \mathrm{~km}$ long, extending 


\section{Pastoral and irrigation landscapes on the Mughan Steppe}
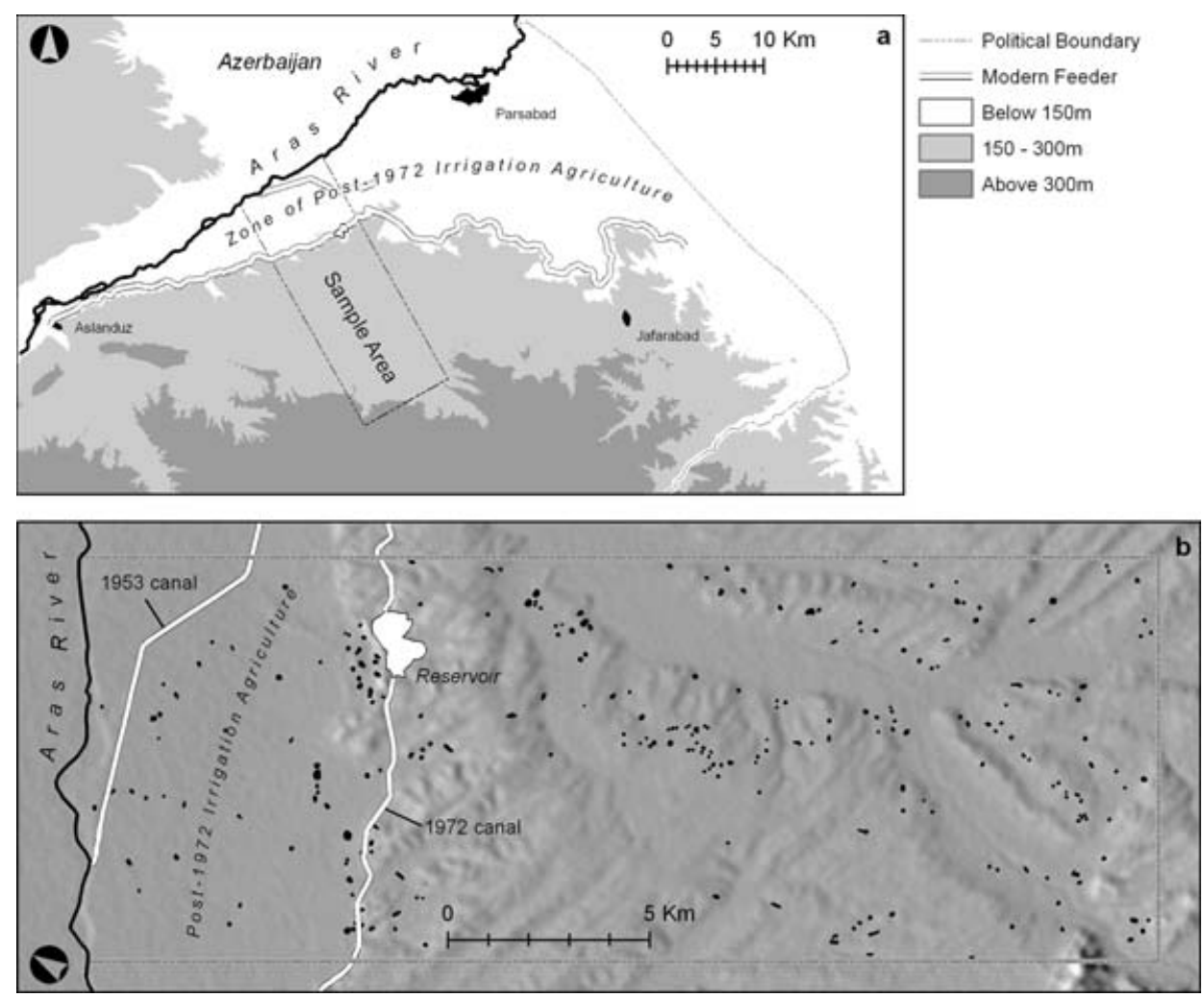

Figure 6. Nomad campsites derived from CORONA photographs. a. Location of $267 \mathrm{~km}^{2}$ sample area; $b$. distribution of campsites. For elevation profile along the south-west edge of the sample area, see Figure 7.

perpendicularly from the Aras (Figure 6). Within this $267 \mathrm{~km}^{2}$ area, 261 campsites could be identified for a density of 0.98 campsites per square kilometre. However, the distribution is uneven; the majority of the campsites appear to cling to the edges of the larger drainages, probably for ease of access to water from wells sunk into their bottoms.

Given that our observations were limited to the low density surface material, the chronological placement of the campsites remains unclear. It is certain that the distribution in Figure 6 represents many non-contemporary camps. However, the late history of the Shahsevan offers some hints toward a general dating of our campsite distribution. The Shahsevan's pastoral economy suffered from the closure of the Russian frontier in 1884, which cost them access to almost two-thirds of their former grazing grounds (Tapper 1983; Tapper 1997: Maps 6-7). Prior to this time, the best grazing was along the Aras and Kur river banks to the north-east; the central part of the plain and the foothills to the south were considered inferior grazing. With the border closure, some 2000000 animals had to be accommodated on a third of the former pasture. The new situation necessitated a radical transformation of the system of pasture rights, including a more intensive use of the uplands. Although the most weathered campsites might substantially predate the Shahsevan, we suspect that the majority of the abandoned campsites post-date the 1884 border closure. Still, they are not recent: local villagers, the descendants of former nomads themselves, told 


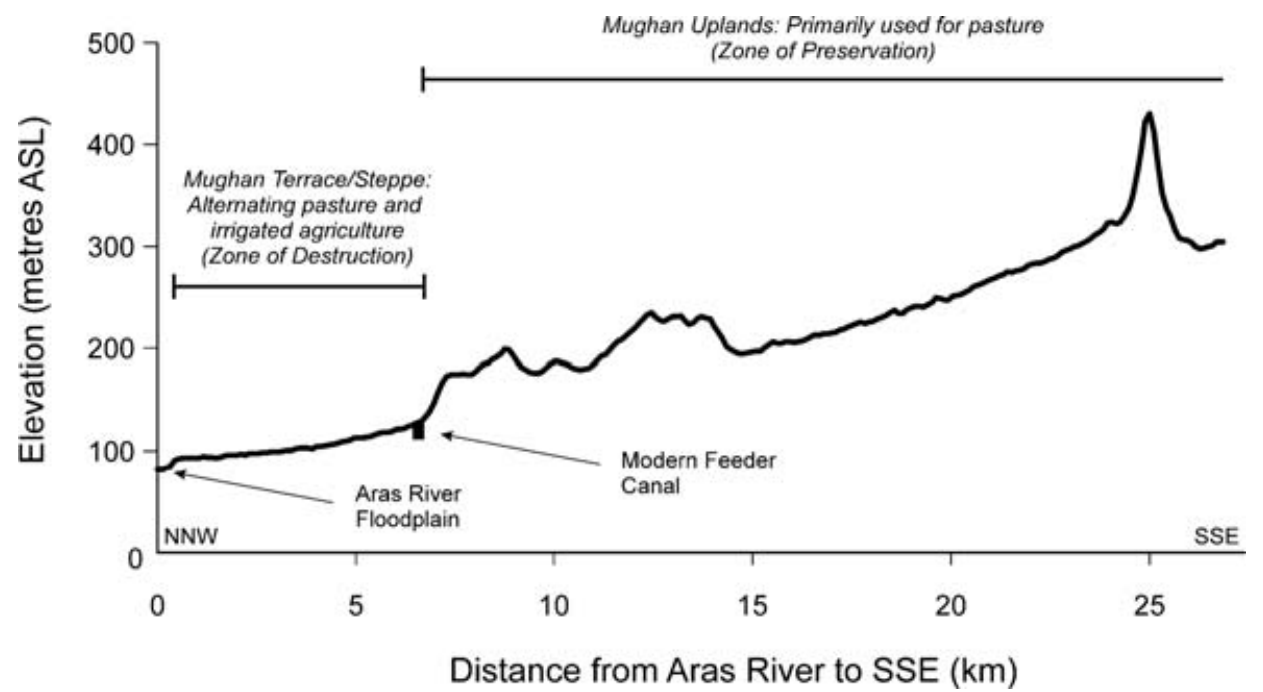

Figure 7. Zones of destruction and preservation on the Mughan Steppe (vertically exaggerated). See Figure 6 for location of this section.

us that these places had not been campsites in their lifetimes, although they were able to correctly identify them as campsites.

\section{The return of intensive irrigation to the steppe}

In the twentieth century, after at least a millennium-long interval of primary use as pasture, the land use pendulum has swung back in the direction of intensive agriculture under a powerful centralised state. After 1884 , the Shahsevan tribes became increasingly troublesome for the Iranian government through continuous raiding. During Reza Shah's 'Wooden Door' programme of the 1930s, many Shahsevan were settled (Tapper 1997: 291-4), and planning for agriculture on the Mughan Steppe began. A trial irrigation system was installed in the neighbourhood of Ultan Qalasi in 1951. In 1971 a joint Soviet-Iranian irrigation project installed a dam across the Aras, enabling the irrigation of 56000 ha on the Iranian side (Schweizer 1974). At this time, almost all of the best pasture on the steppe was under cultivation, encouraging many more pastoralists to settle. This expansion of irrigated agriculture was by no means unique to Mughan but is part of a modernisation program throughout Iran, best known from Khuzistan (Salmanzadeh 1980).

\section{Discussion and conclusions: structured destruction on the Mughan Steppe}

The collapse of the intensive Sasanian irrigation system created a void on the steppe which was eventually filled by pastoral nomadic groups. At least some of their campsites were still visible at the time the CORONA photographs were acquired. In the twentieth century, state-sponsored irrigation reappeared, encompassing all of the land formerly within the Sasanian system and beyond. The installation of this modern irrigation system removed 


\section{Pastoral and irrigation landscapes on the Mughan Steppe}

almost all traces of the nomadic pastoral occupation. The agricultural development of the Mughan Steppe has thus resulted in a non-random removal of earlier landscapes that, if not recognised, could mislead any interpretation of the surviving remains.

Using geo-referenced CORONA photographs and GPS receivers as guides, we visited the former locations of several campsites within the irrigated zone. None preserved any of the microtopography which was so visible in the highlands. The surface assemblage at each of these ploughed campsites was limited to two or three sherds. Without these historical satellite photographs, such densities would require intensive field walking transects at very small intervals to be detected, and even then, their correct interpretation as campsites would be difficult.

A ground-based survey, without the benefit of the historical imagery, would thus produce a deceptive pattern: dense pastoral occupation of the uplands and apparent avoidance of, or exclusion from, the lower parts of the steppe. Our study of CORONA photographs shows that this was hardly the case. The long-term density of campsites in the uplands above the irrigated zone $\left(1.02\right.$ per $\left.\mathrm{km}^{2}\right)$ was nearly identical to the density on the now-irrigated lower steppe $\left(0.86\right.$ per $\left.\mathrm{km}^{2}\right)$. Qualitative ethnographic and historical data confirm this assessment (Tapper 1979; 1997).

On the Mughan Steppe, fortuitously timed remote sensing data allow us to demonstrate the structured destruction which the Taylor-Williamson taphonomic model supposed for the English landscape. Although presently we can only document the most recent instance of this process, we strongly suspect that similar processes may have accompanied earlier agricultural expansion events as well. In our brief first season, we have found some tantalising evidence of pre-Sasanian settlement in the central part of the steppe which was heavily irrigated under the Sasanians and is once more today. It is likely that they were part of much more elaborate landscapes which were transformed already by the Sasanian irrigation; this would explain why CORONA photographs of the steppe show impressively coherent traces of a large irrigation system but none of the other landscape features known from CORONA elsewhere (Ur 2003; 2005). Just as the remains of Shahsevan camps have vanished under modern irrigation, the campsites of earlier nomadic peoples (for example, the Trialeti; Rubinson 1977) may have been erased by Sasanian irrigation. These are issues to be investigated in our future field seasons.

Although broad landscape transformations may not be unique to the modern era, mechanised agricultural and earthmoving technologies now allow their scale to exceed any earlier transformations. We have focused on the impact on the relatively ephemeral remains of nomadic campsites, but such technologies permit the transformation of elements of Wilkinson's more robust signature landscapes as well. In Mughan, for example, twentiethcentury development has not only removed campsites but also substantial canals and mounded settlements. In some cases, all that survives of impressive ancient landscapes is what has been captured by CORONA and aerial photography.

\section{Acknowledgements}

The 2005 Mughan Steppe Archaeological Project gratefully acknowledges the encouragement and support of Dr Massoud Azarnoush, director of the Iranian Center for Archaeological Research; Mr K. Hadjizadeh, director of the Ardebil branch of the Iranian Cultural Heritage and Tourism Organization; and Mr M. Mohammadzadeh, 
deputy governor of Parsabad. Our team members also included Mr Mohammad Feizkhah, Mr Mir Rouhollah Mohammadi, Mr Mohammad Reza Ghadri and Mr Mir Ne'mat Behboudi. GIS research assistance was provided by Christopher Yudelson, Stony Brook University. This text benefited from critical comments by Abbas Alizadeh, St John Simpson, Richard Tapper and two anonymous referees; the authors are solely responsible for any remaining shortcomings.

\section{References}

AвDI, K. 2003. The Early Development of Pastoralism in the Central Zagros Mountains. Journal of World Prehistory 17: 395-448.

Aвu Dulaf. 1955. Travels in Iran (circa AD 950). Translated by V. Minorsky. Cairo: Cairo University Press.

Adams, R.M. 1965. Land Behind Baghdad. Chicago: University of Chicago Press.

AL-TABari. 1999. The Sasanids, the Byzantines, the Lakhmids, and Yemen. Translated by C.E. Bosworth. Albany: State University of New York Press.

Alizadeh, A., N. Kouchoukos, T.J. Wilkinson, A.M. Bauer \& M. Mashkour. 2004.

Human-Environment Interactions on the Upper Khuzestan Plains, Southwest Iran: Recent Investigations. Paléorient 30: 69-88.

Alizadeh, K. 2004. First Preliminary Report of Excavations in Ultan Qalasi, Mughan Steppe, 1382. Unpublished report, Iranian Center for Archaeological Research (in Persian).

Buccellati, G. 1966. The Amorites of the Ur III Period. Naples: Istituto Orientale di Napoli.

Christensen, P. 1993. The Decline of Iranshahr: Irrigation and Environments in the History of the Middle East, 500 BC to AD 1500. Copenhagen: Museum Tusculanum Press.

Crawford, O.G.S. 1953. Archaeology in the Field. London: Phoenix House Ltd.

Cribb, R. 1991. Nomads in Archaeology. Cambridge: Cambridge University Press.

Curtis, V.S., R. Hillenbrand \& J.M. Rogers (ed.). 1998. The Art and Archaeology of Ancient Persia: New Light on the Parthian and Sasanian Empires. London: I.B. Taurus.

Dodgeon, M.H. \& S.N.C. Lieu. 1991. The Roman Eastern Frontier and the Persian Wars AD 226-363: A Documentary History. London \& New York: Routledge.

Fowler, M.J.F. 2004. Archaeology through the Keyhole: The Serendipity Effect of Aerial Reconnaissance Revisited. Interdisciplinary Science Reviews 29: 118-34.

FrYe, R.N. 1977. The Sasanian System of Walls for Defense, in M. Rosen-Ayalon (ed.) Studies in Memory of Gaston Wiet: 7-15. Jerusalem: Hebrew University.
-1983. The Political History of Iran under the Sasanians, in E. Yarshater (ed.) The Cambridge History of Iran, Vol. 3(1): The Seleucid, Parthian and Sasanian Periods: 116-80. Cambridge: Cambridge University Press.

Gheyle, W., R. Trommelmans, J. Bourgeois, R. Goossens, I. Bourgeois, A. De Wulf $\&$ T. Willems. 2004. Evaluating CORONA: a case study in the Altai Republic (South Siberia). Antiquity 78: 391-403.

Gyselen, R. 2002. Nouveaux matériaux pour la géographie historique de l'empire sassanide: sceaux administratifs de la collection Ahmad Saeedi. Paris: Association pour l'avancement des études iraniennes.

Huyse, P. 1999. Die dreisprachige Inschrift Šäbuhrs I. an der Ka'ba-i Zardušt (SKZ). London: Corpus Inscriptionum Iranicarum.

Le Strange, G. 1905. The Lands of the Eastern Caliphate: Mesopotamia, Persia, and Central Asia from the Moslem Conquest to the Time of Timur. Cambridge: Cambridge University Press.

Mohammadi, M.R. 2004. Parthian and Sassanid Periods in Mughan Steppe: Based on Nader Tepe (Nadir Tepesi), Aslandouz. Unpublished MA thesis, University of Tehran (in Persian).

Neely, J.A. 1974. Sassanian and Early Islamic Water-Control and Irrigation Systems on the Deh Luran Plain, Iran, in T.E. Downing \& M. Gibson (ed.) Irrigation's Impact on Society: 21-42. Tucson: University of Arizona.

Op't Land, C. 1966. The Admirable Tents of the Shah Sevan. Internationales Archiv für Ethnographie 50: 237-43.

Pigulevskaja, N. 1963. Les villes de l'état Iranien aux époques parthe et sassanide. Paris: Mouton.

Rubinson, K.S. 1977. The Chronology of the Middle Bronze Age Kurgans at Trialeti, in L.D. Levine \& T.C. Young (ed.) Mountains and Lowlands: Essays in the Archaeology of Greater Mesopotamia: 235-49. Malibu: Undena.

Sagona, A.G. 1984. The Caucasian Region in the Early Bronze Age. BAR International Series 214. Oxford: Archaeopress.

Salmanzadeh, C. 1980. Agricultural Change and Rural Society in Southern Iran. Cambridge: Middle East \& North African Studies. 


\section{Pastoral and irrigation landscapes on the Mughan Steppe}

Salzman, P.C. 2004. Pastoralists: Equality, Hierarchy, and the State. Boulder: Westview Press.

Schweizer, G. 1970. Nordost-Azerbaidschan und Shah Sevan-Nomaden, in E. Ehlers, F. Scholz \& G. Schweizer (ed.) Strukturwandlungen im nomadisch-bäuerlichen Lebensraum des Orients: 81-148. Wiesbaden: Franz Steiner Verlag.

-1974. The Aras-Moghan Development Project in Northwest Iran and the Problem of Nomad Settlement. Applied Sciences and Development 4: 134-48.

Simpson, St.J. 1996. From Tekrit to the Jaghjagh: Sasanian Sites, Settlement Patterns and Material Culture in Northern Mesopotamia, in K. Bartl \& S.R. Hauser (ed.) Continuity and Change in Northern Mesopotamia from the Hellenistic to the Early Islamic Period: 87-126. Berlin: Dietrich Reimer.

-2000. Mesopotamia in the Sasanian Period: Settlement Patterns, Arts and Crafts, in J. Curtis (ed.) Mesopotamia and Iran in the Parthian and Sasanian Periods: Rejection and Revival c. 238 $B C-A D$ 642: 57-80. London: British Museum.

Sмiтh, J.M. 1999. Mongol Nomadism and Middle Eastern Geography: Qishlaqs and Tümens, in R. Amitai-Preiss \& D.O. Morgan (ed.) The Mongol Empire and its Legacy: 39-56. Leiden: Brill.

Tafazzoli, A. 2000. Sasanian Society. New York: Bibliotheca Persica Press.

TAPper, R. 1979. Pasture and Politics: Economics, Conflict and Ritual among Shahsevan Nomads of Northwestern Iran. London \& New York: Academic Press.
-1983. Nomads and Commissars in the Mughan Steppe: The Shahsevan Tribes in the Great Game, in R. Tapper (ed.) The Conflict of Tribe and State in Iran and Afghanistan: 401-35. New York: St. Martin's Press.

-1997. Frontier Nomads of Iran. Cambridge: Cambridge University Press.

TAYLOR, C.C. 1972. The Study of Settlement Patterns in Pre-Saxon Britain, in P.J. Ucko, R. Tringham \& G.W. Dimbleby (ed.) Man, Settlement and Urbanism: 109-13. London: Duckworth.

$U_{R}$, J.A. 2003. CORONA satellite photography and ancient road networks: a northern Mesopotamian case study. Antiquity 77: 102-15.

-2005. Sennacherib's Northern Assyrian Canals: New Insights from Satellite Imagery and Aerial Photography. Iraq 67: 317-45.

Wenke, R.J. 1989. Western Iran in the Partho-Sasanian Period: The Imperial Transformation, in F. Hole (ed.) The Archaeology of Western Iran: 251-81. Washington DC \& London: Smithsonian Institution Press.

Wilkinson, T.J. 2003. Archaeological Landscapes of the Near East. Tucson: University of Arizona Press.

Williamson, T. 1998. Questions of Preservation and Destruction, in P. Everson \& T. Williamson (ed.) The Archaeology of Landscape: Studies Presented to Christopher Taylor: 1-24. Manchester \& New York: Manchester University Press. 